\title{
Technological Transformation
}

\begin{abstract}
Most research on the economic implications of automation has so far focused on advanced industrialized economies where the cost of labor is high and manufacturing shows a high degree of mechanization and productivity. Yet, the developing world is likely to be both affected by automation trends in high-income countries (HICs) and is itself catching up in terms of automation. "Late developers" are facing the digital revolution earlier and under different conditions than today's advanced economies. There is an increasing worry that any low-cost labor advantage of developing countries in international trade is eroding. Beyond the alarmist threat of "technological unemployment," there are broader questions to be asked about how automation and digitization influence global economic development, employment growth, and structural transformation.
\end{abstract}

Keywords Automation - Robots - Artificial intelligence • Digital revolution - Technological adoption - Automatability

\subsection{Contemporary Technological Trends}

Stunning technological advances in robotics and artificial intelligence (AI) are being reported virtually on a daily basis: from the versatile mobile robots of the US engineering company Boston Dynamics to

(C) The Author(s) 2020

L. Schlogl and A. Sumner, Disrupted Development and the Future of Inequality in the Age of Automation, Rethinking International Development series, https://doi.org/10.1007/978-3-030-30131-6_4 
autonomous vehicles, vessels, and drones, to 3D-printed buildings and new breakthroughs in machine learning made by firms in the Silicon Valley and beyond. A growing number of empirical studies and several monographs have recently addressed the broader phenomenon of a "digital revolution" which is unfolding at high speed across OECD countries. Interest in the impact of technological change is by no means new of course as the detailed empirical study of Leontief and Duchin (1984) is testimony to. Indeed, one can trace the subject back to the classical writings of David Ricardo (2010 [1817]) and Karl Marx (2012 [1867]) or Joseph Schumpeter (1943). The bulk of research on the economic implications of digital transformation has so far focused on advanced industrialized economies where the cost of labor is high and manufacturing shows a high degree of mechanization and productivity. Yet, the developing world is both affected by automation trends in high-income countries (HICs) and is itself catching up in terms of automation.

Indicative of this, the International Federation of Robotics (IFR) reports that Asia is currently the "strongest growth market" in a "significant rise in demand for industrial robots worldwide" (IFR, 2016, pp. 1lf.). A double-digit growth trend includes not only China, Korea, and Japan but also emerging economies in South East Asia. The IFR (2016) estimates that by 2019 , more than 250,000 units of multipurpose industrial robots will be installed in Asia on a yearly basis, with the main industries driving demand in robots being the automotive, electrical/electronics, metal, and machinery, as well as the rubber and plastics industries. This only captures the more easily measurable demand for robotics hardware and does not take account of the widespread use of software in the context of economic production. In some domains of automation, emerging economies are, in fact, ahead of many OECD countries, as the opening of Beijing's first driverless subway line in 2017 (Yan, 2017) or the popularity of the mobile phone-based financing platform M-Pesa in Kenya illustrate.

The digitization and automation of economies raises the question of what lessons the developing world can draw from extant evidence. "Late developers" are facing the digital revolution considerably earlier and under different conditions than today's advanced economies. There is thus an increasing worry that "increased automation in lowwage countries, which have traditionally attracted manufacturing firms, could see them lose their cost advantage and potentially lose their ability of achieving rapid economic growth by shifting workers to factory jobs" 
which today's HICs used to have (Frey, Osborne, \& Holmes, 2016). Beyond the perceived threat of "technological unemployment," there are broader questions to be asked about how automation and digitization influence economic development, employment growth, and structural transformation in developing countries. It may well be that labor displacement is less of an issue than real-wage growth as a result of the potential for automation, for example.

\subsection{Automation: Definitions and Determinants}

The concept of automation is more difficult to define than might seem at first glance. Throughout history, humans have used tools to save time and effort when completing laborious tasks and thanks to innovation, such tools have gradually increased in sophistication. Today, the spectrum of "physical capital" ranges from simple manual tools to intelligent machines. One could thus argue that a "robot" is simply a highly advanced version of a tool which requires minimal (manual) human input for completing a task, although currently all machines still require considerable human intervention in their design, production, installation, and maintenance. The potential of $\mathrm{AI}$ is to move machines beyond human oversight, at least in everyday operation. An intelligent machine performs a set of complex tasks autonomously and may be capable of adapting to new and changing circumstances, i.e. "learning." Workhorse animals could be considered a biological equivalent of complex machines and have been used in transportation and agriculture since at least the agricultural revolution in 10,000 BC. Contemporary automation often tends to be associated with physical hardware such as industrial robots, but also includes software which plays a critical role in service automation (see Lacity \& Willcocks, 2018; Willcocks \& Lacity, 2016). The wider process of structural economic change toward an automated economy has been referred to not only as a digital transformation but as the "fourth industrial revolution" (Schwab, 2016).

Under what conditions might such a transformation or revolution take place? Technological feasibility is just one condition. Table 4.1 shows multiple criteria which the decision to automate involves: can a task be automated in a way that reliably produces a good or service at a specified level of quality? Is it profitable to automate that task? Is it legally possible for a firm to replace workers with machines? How do relevant stakeholders such as political groupings, particularly trade unions, and 
Table 4.1 Determinants of the feasibility of automation

\begin{tabular}{|c|c|c|}
\hline Dimension & Factors & Literature \\
\hline Technological & Type and complexity of the task & $\begin{array}{l}\text { Engineering studies, "jobs at risk" } \\
\text { studies } \\
\text { (e.g. Arntz, Gregory, \& Zierahn, } \\
\text { 2016; Grace, Salvatier, Dafoe, } \\
\text { Zhang, \& Evans, 2017; McKinsey } \\
\text { Global Institute, 2017a) }\end{array}$ \\
\hline Economic & $\begin{array}{l}\text { Economic risks and returns given } \\
\text { capital and labor costs; intensity of } \\
\text { competition }\end{array}$ & $\begin{array}{l}\text { Management/human resources } \\
\text { and economics literature } \\
\text { (e.g. Hall \& Khan, 2003; Siegel, } \\
\text { Waldman, \& Youngdahl, 1997) }\end{array}$ \\
\hline Legal & $\begin{array}{l}\text { Labor and capital regulation } \\
\text { (e.g. job protection); patents and } \\
\text { their ownership }\end{array}$ & $\begin{array}{l}\text { Institutionalism and political } \\
\text { economy } \\
\text { (e.g. Acemoglu \& Robinson, }\end{array}$ \\
\hline Political & $\begin{array}{l}\text { e.g. unionization of the workforce; } \\
\text { questions of public versus private } \\
\text { ownership of production and } \\
\text { technology }\end{array}$ & $\begin{array}{l}\text { 2000; Parente \& Prescott, 1994; } \\
\text { Williams \& Edge, 1996) }\end{array}$ \\
\hline Sociocultural & $\begin{array}{l}\text { e.g. corporate legitimacy and social } \\
\text { expectations }\end{array}$ & \\
\hline
\end{tabular}

Source Authors and references cited

society at large, particularly consumers, respond to automation (and the potentially ensuing lay-offs)?

Corresponding to these criteria, one could split the literature on automation into different theoretical approaches. Much recent research has focused on the first criterion in Table 4.1: the technological feasibility of automation. Yet, automatable tasks do not necessarily or instantly get automated: one can observe a set of tasks currently being carried out both by humans and machines in different contexts and places. Consider, for instance, subway drivers and autonomous subways, supermarket cashiers, and self-checkout machines, university lecturers, and online courses. The coexistence of automated and nonautomated modes of operation of the same task suggests that a narrowly technologically deterministic view is insufficient. There are less tangible-economic, political, social, and cultural-reasons to be factored in. Such factors up until now often seem to have been neglected in research on automation, but could be particularly important in the context of developing countries. Such factors not only determine if automation occurs but the terms of automation vis-à-vis governing institutions. 
Consider, for example, the case of Indonesia. In Indonesia, there have been numerous media reports related to automation and employment impacts (e.g. Deny, 2017; Jakarta Globe, 2017; Jefriando, 2017; Praditya, 2017; Saragih, 2017; Tempo, 2015, 2016a, 2016b, 2016c, 2017; see also international press such as The Guardian, 2016). The McKinsey Global Institute (2017b) estimates that around half of all jobs in Indonesia are automatable using existing technologies. One example is that motorway toll booths are being automated to an e-payment system which has placed a question over 20,000 jobs, leading the Minister of Finance to announce at the annual meeting of the International Monetary Fund and the World Bank that automation might create a case for a future universal basic income in Indonesia (Jakarta Post, 2017; Jefriando, 2017).

While formerly each tollgate required five employees working in shifts to ensure vehicles had paid the road toll, the cashless system which is being rolled out runs entirely without human operators, thus speeding up the transaction process and reducing traffic congestion. Yet, as of early 2018, the toll road operator PT Jasa Marga asserts that "former tollgate keepers would instead be relocated to different positions within the company (...) and would keep their permanent employee status" (Aisyah, 2017).

There have, indeed, so far, been no reports of mass lay-offs despite the electronic system being implemented. What could be the reason? First, it could be that, as implementation is still in an early stage, lay-offs may be a matter of time, and could happen in a gradual manner. The company may also reduce its future intake of new employees as a result. Second, it could be that, in line with the quote above, PT Jasa Marga, which is currently expanding its business, truly has the capacity to absorb 20,000 people in other sectors of its operation. If that is the case, this raises the important question as to whether by raising overall productivity and competitiveness, automation somehow allowed the company to expand. The latter would mean that automation has the double effect of reducing labor demand per unit of capital in one domain (e.g. manual toll collection) while raising labor demand in complementary domains (e.g. administrative or construction tasks).

Finally, there is a set of institutional reasons that could be an important explanatory factor as to why PT Jasa Marga-a state-owned enterprise and thus facing potential developmental obligations-has not laid off workers: political and social-norms pressures as well as 
legal constraints could be preventing the toll road operator from firing employees. One could imagine the political backlash of a state-owned enterprise making 20,000 people unemployed. There may be also concerns over strikes, attacks on the new toll-booth machinery, political interventions (including fears of the political replacement of senior management making such decisions) or negative media reports which demonstrably influence business decisions in part of wholly owned SOEs and to some extent in private companies too.

\subsection{Theoretical Perspectives on Automation}

One could crudely distinguish the existing scholarly literature on automation and digitization effects into two camps: first, there is an optimists' camp which essentially sees the "business as usual" of market dynamism at work. Technological change, they argue, has been an essential element of "modern economic growth" since the Industrial Revolution, and disruptive innovation has always been met with what Mokyr, Vickers, and Ziebarth (2015) call "technological anxiety." This has been the case at least since the arrival of the steam engine and the power loom. Simon Kuznets (1971) in his Nobel lecture argued that the most important feature of modern economic growth is a "combination of a high rate of aggregate growth with disrupting effects and new 'problems'." Such disruption refers, in particular, to changes in the economic and social structure that technological innovation generates.

Joseph Schumpeter, key theorist of technological innovation, famously coined the notion of "creative destruction" for the "process of industrial mutation that incessantly revolutionizes the economic structure from within, incessantly destroying the old one, incessantly creating a new one" and called this the "essential fact about capitalism" (Schumpeter, 1943 , pp. 42f., emphasis in original). Schumpeter's view on the economics of technology in the context of the Industrial Revolution preceded the neoclassical standard model of growth advanced by Solow (1956). In his aggregate production function, Solow attributed all output growth not accounted for by increases in capital and/or labor to a broad category of “technical change" (Granstrand, 1994, p. 13).

Scholars in this optimistic tradition thus tend to emphasize the historically demonstrated adaptive capacity of market economies to innovation and change with little emphasis on any temporary or permanent "losers" in the process. Further, they argue that robots and computers take over 
repetitive, dangerous, unhealthy tasks, and so improve both the quality of work and of products and come with public health benefits. Importantly, automation decreases the cost of production and should thus, in a competitive market, lead to lower prices which benefit all consumers. Not only this, but "automation, by reducing wages relative to the rental rate of capital, encourages the creation of new labor-intensive tasks and generates a powerful self-correcting force towards stability" (Acemoglu \& Restrepo, 2015, p. 41). Optimists tend to suggest skills development for the labor force to allow a synergetic relationship of human and nonhuman work. This is in keeping with Goldin and Katz' (2007) race between technology and skill supply itself drawing on the Tinbergen $(1974,1975)$ thesis. Further, they might advocate to reduce taxes on labor which would make labor relatively more competitive vis-à-vis robots.

The pessimists' camp, on the other hand, argues that "this time it's different": contemporary iterations of automation and digitization are viewed as being part of a larger "digital revolution" (Avent, 2017) which is bringing about technologies that are more powerful and versatile than earlier iterations of the Industrial Revolution, and which will wholly or partially replace human brains rather than just the buman muscle replaced by earlier technologies. The digital revolution, it is argued, is creating an array of intelligent, adaptive, general-purpose technologies with hitherto unseen labor-saving potentials for a widening group of tasks. This group of tasks increasingly includes complex, skill-intensive work and formerly hard-to-automate manual work like stitching. The relationship of human and nonhuman work is viewed as more and more substitutive rather than complementary. In this vein, an in-depth report of the Executive Office of the President of the United States (2016, p. 22) commissioned by Barack Obama warns that "the skills in which humans have maintained a comparative advantage are likely to erode over time as AI and new technologies become more sophisticated." DeLong (2015) argues too that, just like horses once used to dominate economic production, human labor currently dominates it, but that "peak human" may have been reached.

Pessimists argue that automation is putting a downward pressure on wages (reflected in stagnating real wages) and an upward pressure on the rate of profit from capital investment. The detachment of productivity gains and wage growth observed since the 1970s in many OECD countries is brought forward as evidence. Automation, pessimists argue, may ultimately lead to job losses as technologies create fewer jobs than 
they eliminate ("technological unemployment") or create jobs in sectors which are potentially less desirable and productive ("premature deindustrialization"). Politically, the recommendations of the pessimist camp range from a "robot tax" to redistributive responses such as a universal basic income (with the latter potentially funded by the former) and questions of public versus private ownership of production and technology.

It is fair to say that the second, more pessimistic, camp has been increasingly visible in recent years. Yet, unemployment is generally not considered to be the main issue. With a view to the United States, economic experts from the IGM Panel (2014) agree that automation has not (yet) markedly reduced employment but has rather led to a stagnation of median wages, a decoupling of real-wage growth from productivity growth, and a labor market polarization or "hollowing out" of middle-skill employment. Technology can depress or enhance wage growth depending on whether it substitutes or complements tasks (see for discussion, Acemoglu \& Autor, 2011; Autor, Katz, \& Kearney, 2004; Firpo, Fortin, \& Lemieux, 2011; Goos \& Manning, 2007).

Further, it should not be taken as given that lower skilled work will necessarily be automated, but it can contribute to a "missing middle" whereby most jobs are low or high skilled, and those in-between are relatively more susceptible to automation, or whereby employment expansion in those middle-skill jobs is weaker than that of low- and highskilled jobs (see Autor, Levy, \& Murnane, 2003). The problem thus may not be so much that jobs are lost, rather than that other types of jobs expand in number. People are being driven into the jobs below their skill level, with either lower or slower growing wages than the middle-skill jobs that previously existed.

A key question is what happens to productivity growth in any given country. In short, who "captures" the productivity growth in terms of capital or labor and the functional distribution of income. And how what is captured is then distributed within the capital share (which may be distributed between reinvestment, dividend payments, reserves building, or other activity e.g. rents), or within the labor share which may be distributed between employment growth, real-wage growth, or social security entitlements (see discussion of Atkinson, 2009; Francese \& Mulas-Granados, 2015). This matters from an individual income inequality perspective, as reductions in the labor share of income are correlated with rising income inequality between individuals (see for detailed discussion, Chapter 3 of IMF, 2017). 


\section{REFERENCES}

Acemoglu, D., \& Autor, D. (2011). Skills, tasks and technologies: Implications for employment and earnings. In O. Ashenfelter \& D. Card (Eds.), Handbook of labor economics (Vol. 4B, pp. 1043-1171). Amsterdam: Elsevier.

Acemoglu, D., \& Restrepo, P. (2015). The race between machine and man: Implications of technology for growth, factor shares and employment. SSRN Electronic Journal. https://doi.org/10.2139/ssrn.2781320.

Acemoglu, D., \& Robinson, J. A. (2000). Political losers as a barrier to economic development. American Economic Review Papers and Proceedings, 90, 126-130.

Aisyah, R. (2017, November 3). No layoffs after full cashless payment: Toll road operator. The Jakarta Post. Retrieved from http://www.thejakartapost.com/ news $/ 2017 / 11 / 03 /$ no-layoffs-after-full-cashless-payment-toll-road-operator. html.

Arntz, M., Gregory, T., \& Zierahn, U. (2016). The risk of automation for jobs in OECD countries: A comparative analysis. OECD Social, Employment and Migration Working Papers, 2(189), 47-54.

Atkinson, A. B. (2009). Factor shares: The principal problem of political economy. Oxford Review of Economic Policy, 25(1), 3-16.

Autor, D. H., Katz, L. F., \& Kearney, M. S. (2004). The polarization of the U.S. labor market. AEA Papers and Proceedings, 96(2), 189-194.

Autor, D. H., Levy, F., \& Murnane, R. J. (2003). The skill content of recent technological change: An empirical exploration. The Quarterly Journal of Economics, 118(4), 1279-1333.

Avent, R. (2017). The wealth of humans: Work and its absence in the twenty-first century. London: Penguin Random House.

DeLong, B. (2015). Technological progress anxiety: Thinking about "peak horse" and the possibility of "peak human". Retrieved from http://equitablegrowth.org/equitablog/technological-progress-anxiety-thinking-about-peak-horse-and-the-possibility-of-peak-human/.

Deny, S. (2017, August 24). Sri mulyani khawatir generasi muda ri kalah dengan robot. Liputan 6. Retrieved from http://bisnis.liputan6.com/ $\mathrm{read} / 3069606 /$ sri-mulyani-khawatir-generasi-muda-ri-kalah-dengan-robot.

Executive Office of the President of the United States. (2016). Preparing for the future of artificial intelligence. Washington, DC. Retrieved from https:// obamawhitehouse.archives.gov/sites/default/files/whitehouse_files/ microsites/ostp/NSTC/preparing_for_the_future_of_ai.pdf.

Firpo, S. P., Fortin, N. M., \& Lemieux, T. (2011). Occupational tasks and changes in the wage structure (IZA Discussion Paper No. 5542). Bonn: IZA. Retrieved from ftp.iza.org/dp5542.pdf. 
Francese, M., \& Mulas-Granados, C. (2015). Functional income distribution and its role in explaining inequality (IMF Working Papers 15/244). Washington, DC: IMF. Retrieved from https://www.imf.org/en/Publications/WP/ Issues /2016/12/31/Functional-Income-Distribution-and-Its-Role-inExplaining-Inequality-43415.

Frey, C. B., Osborne, M. A., \& Holmes, C. (2016). Technology at work v2.0: The future is not what it used to be (Citi GPS: Global Perspectives \& Solutions). Oxford. Retrieved from http://www.oxfordmartin.ox.ac.uk/downloads/ reports/Citi_GPS_Technology_Work_2.pdf.

Goldin, C., \& Katz, L. F. (2007). The race between education and technology: The evolution of U.S. educational wage differentials, 1890 to 2005 (NBER Working Paper Series No. 12984). Cambridge, MA: NBER. Retrieved from http:// www.nber.org/papers/w12984.

Goos, M., \& Manning, A. (2007). Lousy and lovely jobs: The rising polarization of work in Britain. Review of Economics and Statistics, 89(1), 118-133.

Grace, K., Salvatier, J., Dafoe, A., Zhang, B., \& Evans, O. (2017). When will AI exceed human performance? Evidence from $A I$ experts (arXiv No. 1705.08807v2). Retrieved from http://arxiv.org/abs/1705.08807.

Granstrand, O. (1994). Economics of technology. Amsterdam: North-Holland.

Hall, B. H., \& Khan, B. (2003). Adoption of new technology (NBER Working Paper Series No. 9730). Cambridge, MA: NBER. Retrieved from http://www.nber.org/papers/w9730.

IFR. (2016). Executive summary: World robotics 2016 service robots (International Federation of Robotics). Retrieved from http://www.ifr.org/fileadmin/ user_upload/downloads/World_Robotics/2016/Executive_Summary_WR_ Industrial_Robots_2016.pdf.

IGM Panel. (2014, February 25). Robots. IGM Forum. Retrieved from http:// www.igmchicago.org/surveys/robots.

IMF. (2017). World economic outlook, April 2017: Gaining momentum? Washington, DC: IMF. Retrieved from http://www.imf.org/en/Publications / WEO/Issues/2017/04/04/world-economic-outlook-april-2017.

Jakarta Globe. (2017, October 13). Indonesia to consider universal basic income. Jakarta Globe. Retrieved from http://jakartaglobe.id/business/ indonesia-to-study-universal-basic-income/.

Jakarta Post. (2017, September 14). Non-cash toll will affect 10,000 workers in Jakarta. The Jakarta Post. Retrieved from http://www.thejakartapost.com/ news /2017/09/14/non-cash-toll-will-affect-10000-workers-in-jakarta.html.

Jefriando, M. (2017, October 12). Sri mulyani bicara soal robot ancam pekerjaan manusia. Detik. Retrieved from https://finance.detik.com/beritaekonomi-bisnis/3680492/sri-mulyani-bicara-soal-robot-ancam-pekerjaan-manusia. 
Kuznets, S. (1971). Modern economic growth: Findings and reflections: Lecture to the memory of Alfred Nobel. Stockholm: The Nobel Foundation. Retrieved from http://www.nobelprize.org/nobel_prizes/economic-sciences/laureates/1971/kuznets-lecture.html.

Lacity, M., \& Willcocks, L. P. (2018). Robotic process and cognitive automation: The next phase. Stratford: Steve Brookes Publishing.

Leontief, W., \& Duchin, F. (1984). The impacts of automation on employment, 1963-2000. CATESOL Journal, 5(1), 1963-2000. Retrieved from http://files.eric.ed.gov/fulltext/ED241743.pdf.

Marx, K. (2012 [1867]). Das Kapital: A critique of political economy. Washington, DC: Regnery Publishing.

McKinsey Global Institute. (2017a). A future that works: Automation, employment, and productivity. Retrieved from https://www.mckinsey.com/ / media/McKinsey/Global\%20Themes/Digital\%20Disruption/Harnessing\%20 automation $\% 20$ for $\% 20 \mathrm{a} \% 20$ future $\% 20$ that $\% 20$ works /MGI-A-future-thatworks_Full-report.ashx.

McKinsey Global Institute. (2017b). Where machines could replace humans-And where they can't (yet). Retrieved from https://public.tableau.com/en-us/s/ gallery/where-machines-could-replace-humans.

Mokyr, J., Vickers, C., \& Ziebarth, N. L. (2015). The history of technological anxiety and the future of economic growth: Is this time different? Journal of Economic Perspectives, 29(3), 31-50.

Parente, S. L., \& Prescott, E. C. (1994). Barriers to technology adoption and development. Journal of Political Economy, 102(2), 298-321.

Praditya, I. I. (2017, August 17). 72 tahun merdeka, ri masih hadapi deindustrialisasi. Liputan 6. Retrieved from http://bisnis.liputan6.com/read/ 3061377/72-tahun-merdeka-ri-masih-hadapi-deindustrialisasi.

Ricardo, D. (2010). On the principles of political economy, and taxation. Urbana, Illinois: Project Gutenberg. http://www.gutenberg.org/files/33310/33310h/33310-h.htm.

Saragih, F. A. (2017, September 16). Otomatisasi tol dianggap kejahatan. Kompas. com. Retrieved from http://ekonomi.kompas.com/read/2017/09/16/0801 00530/otomatisasi-tol-dianggap-kejahatan.

Schumpeter, J. A. (1943). Capitalism, socialism and democracy. Abingdon-onThames: Routledge.

Schwab, K. (2016). The fourth industrial revolution. Geneva: Portfolio Penguin.

Siegel, D. S., Waldman, D. A., \& Youngdahl, W. E. (1997). The adoption of advanced manufacturing technologies: Human resource management implications. IEEE Transactions on Engineering Management, 44(3), 288-298.

Solow, R. M. (1956). A contribution to the theory of economic growth. The Quarterly Journal of Economics, 70(1), 65-94. 
Tempo. (2015, December 14). Provinsi di Indonesia ini alami gejala deindustrialisasi. Tempo.co. Retrieved from https://bisnis.tempo.co/read/727694/ provinsi-di-indonesia-ini-alami-gejala-deindustrialisasi.

Tempo. (2016a, January 12). Bali bans the operation of Uber Taxi. Tempo.co. Retrieved from https://en.tempo.co/read/news/2016/01/21/056738210/ Bali-Bans-the-Operation-of-Uber-Taxi.

Tempo. (2016b, March 21). Protes Uber dan Grab, sopir se-Jakarta akan unjuk rasa. Tempo.co. Retrieved from https://metro.tempo.co/read/755352/protesuber-dan-grab-sopir-se-jakarta-akan-unjuk-rasa.

Tempo. (2016c, September 27). 200 Ribu pekerja terancam phk karena otomatisasi gardu tol. Tempo.co. Retrieved from https://bisnis.tempo.co/ read/807738/200-ribu-pekerja-terancam-phk-karena-otomatisasi-gardu-tol.

Tempo. (2017, February 20). Era Digital, jumlah pengangguran meningkat. Tempo. co. Retrieved from https://tekno.tempo.co/read/848320/era-digital-jumlahpengangguran-meningkat.

The Guardian. (2016, March 22). Traffic chaos and violence as thousands of taxi drivers protest against Uber in Jakarta. The Guardian. Retrieved from https://www.theguardian.com/world/2016/mar/22/traffic-chaosand-violence-as-thousands-of-taxi-drivers-protest-uber-in-jakarta.

Tinbergen, J. (1974). Substitution of graduate by other labour. Kyklos, 27(2), 217-226.

Tinbergen, J. (1975). Substitution of academically trained by other manpower. Review of World Economics, 111(3), 466-476.

Willcocks, Leslie P., \& Lacity, Mary. (2016). Service automation: Robots and the future of work. Stratford: Steve Brookes Publishing.

Williams, R., \& Edge, D. (1996). The social shaping of technology. Research Policy, 25(6), 865-899.

Yan, A. (2017, June 12). Beijing's first driverless subway line starts test run. CGTN. Retrieved from https://news.cgtn.com/news/3d557a4d3249444e/share_p. html. 
Open Access This chapter is licensed under the terms of the Creative Commons Attribution 4.0 International License (http://creativecommons.org/licenses/ by $/ 4.0 /$ ), which permits use, sharing, adaptation, distribution and reproduction in any medium or format, as long as you give appropriate credit to the original author(s) and the source, provide a link to the Creative Commons license and indicate if changes were made.

The images or other third party material in this chapter are included in the chapter's Creative Commons license, unless indicated otherwise in a credit line to the material. If material is not included in the chapter's Creative Commons license and your intended use is not permitted by statutory regulation or exceeds the permitted use, you will need to obtain permission directly from the copyright holder.

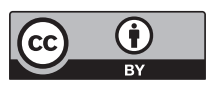

